\title{
Variation of $\mathrm{CO}_{2}$ mole fraction in the lower free troposphere, in the boundary layer and at the surface
}

\author{
L. Haszpra ${ }^{1}$, M. Ramonet ${ }^{2}$, M. Schmidt ${ }^{2}$, Z. Barcza ${ }^{3}$, Zs. Pátkai ${ }^{4}$, K. Tarczay ${ }^{4}$, C. Yver ${ }^{5}$, J. Tarniewicz ${ }^{2}$, and P. Ciais ${ }^{2}$ \\ ${ }^{1}$ Hungarian Meteorological Service, 1675 Budapest, P.O. Box 39, Hungary \\ ${ }^{2}$ Laboratoire des Sciences du Climat et de l'Environnement, UMR8212 CEA-CNRS-UVSQ, 91191 Gif-sur-Yvette, France \\ ${ }^{3}$ Department of Meteorology, Eötvös Loránd University, 1117 Budapest, Pázmány P. sétány 1/A, Hungary \\ ${ }^{4}$ Hungarian Meteorological Service, 1525 Budapest, P.O. Box 38, Hungary \\ ${ }^{5}$ Scripps Institution of Oceanography, UC San Diego, 9500 Gilman Drive, La Jolla, CA 92093 - 0244, USA
}

Correspondence to: L. Haszpra (haszpra.1@met.hu)

Received: 12 April 2012 - Published in Atmos. Chem. Phys. Discuss.: 4 May 2012

Revised: 12 September 2012 - Accepted: 13 September 2012 - Published: 28 September 2012

\begin{abstract}
Eight years of occasional flask air sampling and 3 years of frequent in situ measurements of carbon dioxide $\left(\mathrm{CO}_{2}\right)$ vertical profiles on board of a small aircraft, over a tall tower greenhouse gases monitoring site in Hungary are used for the analysis of the variations of vertical profile of $\mathrm{CO}_{2}$ mole fraction. Using the airborne vertical profiles and the measurements along the $115 \mathrm{~m}$ tall tower it is shown that the measurements at the top of the tower estimate the mean boundary layer $\mathrm{CO}_{2}$ mole fraction during the mid-afternoon fairly well, with an underestimation of 0.27 $0.85 \mu \mathrm{mol} \mathrm{mol}^{-1}$ in summer, and an overestimation of $0.66-$ $1.83 \mu \mathrm{mol} \mathrm{mol}^{-1}$ in winter. The seasonal cycle of $\mathrm{CO}_{2}$ mole fraction is damped with elevation. While the amplitude of the seasonal cycle is $28.5 \mu \mathrm{mol} \mathrm{mol}^{-1}$ at $10 \mathrm{~m}$ above the ground, it is only $10.7 \mu \mathrm{mol} \mathrm{mol}^{-1}$ in the layer of $2500-3000 \mathrm{~m}$ corresponding to the lower free atmosphere above the well-mixed boundary layer. The maximum mole fraction in the layer of 2500-3000 $\mathrm{m}$ can be observed around $25 \mathrm{March}$ on average, two weeks ahead of that of the marine boundary layer reference (GLOBALVIEW). By contrast, close to the ground, the maximum $\mathrm{CO}_{2}$ mole fraction is observed late December, early January. The specific seasonal behavior is attributed to the climatology of vertical mixing of the atmosphere in the Carpathian Basin.
\end{abstract}

\section{Introduction}

Development and increasing use of high-resolution 3dimensional carbon dioxide $\left(\mathrm{CO}_{2}\right)$ transport models require detailed information on the spatial distribution of carbon dioxide in the atmosphere and its temporal variation as both input information and data for validation (Bakwin et al., 2004; Geels et al., 2007; Peters et al., 2007; Stephens et al., 2007; Yang et al., 2007; Engelen et al., 2009; Feng et al., 2011; Patra et al., 2011; Pickett-Heaps et al., 2011). State-ofthe-art atmospheric transport models still have difficulties to reproduce the real vertical mole fraction profiles that may result in errors in the inverted carbon fluxes. The growing need for vertical profile measurements is expressed by several authors of recent papers (e.g. Feng et al., 2011; Pickett-Heaps et al., 2011). The extending network of tall tower monitoring sites may provide data from the lowest $100-500 \mathrm{~m}$ of the atmosphere, but they can only estimate the $\mathrm{CO}_{2}$ mole fraction of the planetary boundary layer (PBL) under well-developed turbulent conditions (Bakwin et al., 1995; Gloor et al., 2001; Vermeulen, 2007). The persistent exchange between the PBL and the lower free troposphere (LFT) through entrainment, overshooting convection, day-to-day variation of the height of the convective boundary layer also requires information on the mole fraction in the LFT and its temporal variation. Calibration/validation of satellite-borne measurements, ground based remote sensing instruments also require detailed mole fraction data from the lower troposphere (Engelen and McNally, 2005; Wunch et al., 2010). This atmospheric layer can

Published by Copernicus Publications on behalf of the European Geosciences Union. 
only be reached by balloons and aircrafts, or by means of specially designed kites (Stone, 1991; Gerbig et al., 2003; Watai et al., 2006; Acevedo et al., 2008; Watai et al., 2009).

For measurement/sampling in PBL and LFT the most common solution is the use of small aircrafts. Recognizing the need of information on the 3-dimensional distribution of $\mathrm{CO}_{2}$ mole fraction and its temporal variation an airborne measurement program was initiated in Europe in 2001 in the framework of AEROCARB (Airborne European regional carbon observations of the carbon balance) project of the 5 th R\&D Framework Programme of the European Commission (http://aerocarb.lsce.ipsl.fr/). Flask air samples were taken on board of small aircrafts above six European tall tower monitoring sites up to $3000 \mathrm{~m}$ above the ground in more or less regular interval (approximately 1 flight/month). The air samples were analyzed at Laboratoire des Sciences du Climat et de l'Environnement (LSCE), France, for $\mathrm{CO}_{2}$ and other major greenhouse gases $\left(\mathrm{CH}_{4}, \mathrm{~N}_{2} \mathrm{O}, \mathrm{SF}_{6}\right)$. This program was continued at most sites in the framework of CarboEurope Integrated Project of the 6th R\&D Framework Programme of the European Commission (http://www.carboeurope.org/) until the end of 2008. At a few aircraft sampling sites this monitoring program was extended by high-frequency airborne measurement campaigns between 2006 and 2008 during which in situ $\mathrm{CO}_{2}$ measurements were carried out between 200 and $3000 \mathrm{~m}$ above the ground approximately 4-8 times per month. Similar airborne monitoring programs have also been developed over North America (http://www.esrl. noaa.gov/gmd/ccgg/aircraft/; Crevoisier et al., 2010).

The present paper evaluates the temporal variation of $\mathrm{CO}_{2}$ mole fraction in the lower free troposphere, in the boundary layer and at the surface using the measurements carried out on and above the tall tower at Hegyhátsál, Hungary, between 2001 and 2008. The parallel tall tower and airborne measurements also offer the opportunity to judge how accurately tall tower measurements can inform the modelers about the mean $\mathrm{CO}_{2}$ mole fraction in the planetary boundary layer.

\section{Methodology}

\subsection{Site, measurement program and instrumentation}

Hegyhátsál tall tower greenhouse gas monitoring site is located in western Hungary $\left(46^{\circ} 57^{\prime} \mathrm{N}, 16^{\circ} 39^{\prime} \mathrm{E}, 248 \mathrm{~m}\right.$ asl Fig. 1) in a fairly flat region, in rural environment, which provides high spatial representativeness to the measurements with respect to regional fluxes. The immediate terrain does not modify the large-scale atmospheric conditions. The large-scale flow pattern at the station may only be influenced by the Alps some $100 \mathrm{~km}$ to the west. At Hegyhátsál tall tower site carbon dioxide dry mole fraction has been continuously monitored at four elevations $(10 \mathrm{~m}, 48 \mathrm{~m}, 82 \mathrm{~m}$ and $115 \mathrm{~m}$ above the ground) since September 1994, using a nondispersive infrared gas analyzer (1994-2007: Li-Cor Model

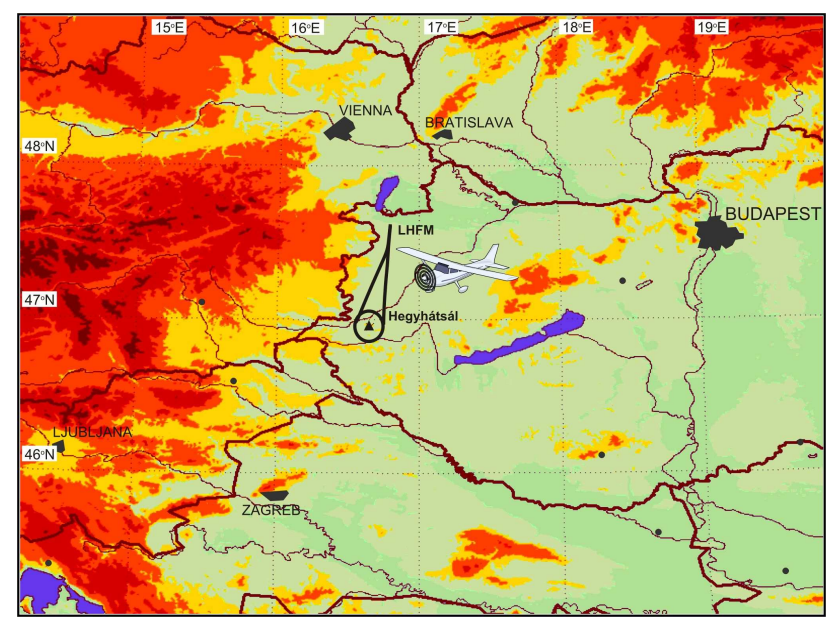

Fig. 1. Location of Hegyhátsál tall tower greenhouse gas monitoring site and the flight route of the airplane.

LI-6251, from 2007: Li-Cor Model LI-7000) (Haszpra et al., 2001; 2010). Quality of the measurements is assured by use of standards produced and certified by the World Meteorological Organization Central Calibration Laboratory for $\mathrm{CO}_{2}$ (WMO CCL) operated by the Earth System Research Laboratory of the National Oceanic and Atmospheric Administration (NOAA ESRL), USA, and by the comparison with co-located NOAA flask air sample measurements (NOAA co-operative air sampling network, site code: HUN - http://www.esrl.noaa.gov/gmd/ccgg/flask.html) (Haszpra et al., 2010), as well as through regular international intercomparisons (Manning et al., 2009). Human habitations within $10 \mathrm{~km}$ of the tower are only small villages (100-400 inhabitants). The nearest village is Hegyhátsál (170 inhabitants) about $1 \mathrm{~km}$ to the northwest. There is no notable industrial activity in this dominantly agricultural region. Local roads have mostly low levels of traffic. The site can be considered as rural in the industrialized, densely populated Central Europe, as it was shown by $\mathrm{SF}_{6}$ measurements (Haszpra et al., 2008). A detailed description of the site and instrumentation can be found in Haszpra et al. $(2001 ; 2005 ; 2010)$ or at the website of the station (http://nimbus.elte.hu/hhs/).

Airborne measurements were started on 18 July 2001, in the framework of the AEROCARB project, and continued until 18 January 2009. In 2001-2002 a Cessna-172, in 20032004 a Mooney-205, while from mid-2004 a Cessna-210 aircraft was used. In the case of Cessna-172 and Mooney-205 the ventilation duct of the cabin was used for air intake, while in the case of Cessna-210 a dedicated intake was mounted on the top of the cabin. These locations proved free from exhaust gases. The aircrafts took off at Fertôszentmiklós airport (LHFM - http://www.lhfm.hu/), approximately $40 \mathrm{~km}$ north off Hegyhátsál tall tower site.

For flask air sampling a custom-made sampling unit manufactured by LSCE was installed, which could accommodate 
two glass flasks of 11 in series. The flasks were made of Pyrex glass with PFA O-ring valves at both ends. Flushing rate was about $41 \mathrm{~min}^{-1}$. The sample air was dried by anhydrous magnesium perchlorate. According to the sampling protocol accepted for the AEROCARB project air samples were taken at seven elevations $(200 \mathrm{~m}, 500 \mathrm{~m}, 1000 \mathrm{~m}$, $1500 \mathrm{~m}, 2000 \mathrm{~m}, 2500 \mathrm{~m}, 3000 \mathrm{~m}$ above the ground). At three elevations $(1000 \mathrm{~m}, 2000 \mathrm{~m}, 2500 \mathrm{~m})$ a pair of flasks in serial order was filled, while on the other sampling levels only single flasks were used. During each flight a total of ten flasks were filled up to 1 bar overpressure above ambient one, and shipped to LSCE for analysis within the shortest possible time. The samples were analyzed by means of a gas chromatograph system. The standards applied for the calibration of the system were also traceable to WMO CCL standards. Between sampling and analysis the samples were stored in dark at room temperature. Flask air samples were taken in 3-5 weeks interval during the whole duration of the program with occasional longer gaps for technical/logistic reasons.

For the in situ airborne measurements an AOS Airborne $\mathrm{CO}_{2}$ Analyzer System (Atmospheric Observing Systems, Inc., Boulder, Colorado, USA) was used. This temperature and pressure controlled non-dispersive infrared gas analyzer could provide $1 \mathrm{~s}$ temporal resolution at a nominal accuracy comparable with that of the standards used for the calibration. The sample air was dried by anhydrous magnesium perchlorate. The instrument compartment accommodated two small tanks ("field tanks") regularly refilled with WMO CCL certified standard gases $\left(375.47 \mu \mathrm{mol} \mathrm{mol}^{-1}\right.$, $390.47 \mu \mathrm{mol} \mathrm{mol}^{-1}$ - concentration values are expressed in the SI recommended $\mu \mathrm{mol} \mathrm{mol}^{-1}$ unit [dry mole fraction] throughout the paper; the values are numerically equal to those expressed in the widely used ppm unit) for the calibration of the instrument. During the flight the instrument was calibrated in every 25 th min, which were complemented by a so-called 'baseline' check in every 150th s to compensate any scale-drift. For the baseline-check the standard of lower mole fraction was used. The contents of the field tanks were compared with that of their "mother" tanks before and after each refill. Because the deviations experienced were typically lower than the expected measurement uncertainty and the temporal course of any drift was also uncertain no correction was applied on the raw data.

Measurements were performed between 10 February and 12 November 2006, with a longer gap in summer, as well as between 8 November 2007, and 18 January 2009. During each flight an ascending and a descending profile were measured. Comparison of the two profiles provided information on the performance of the instrument under persistent weather conditions. Elevation change of concentration jumps between the ascending and descending profiles might indicate changes in the stratification of the atmosphere. Both flask air samplings and in situ measurements were performed during the late morning - early afternoon hours when the vertical mixing of the PBL is the most intensive, especially in summertime. Although, the convective PBL is often still developing around noontime occasionally the conditions forced the earlier flights. In some cases these flights gave information on the quickly developing PBL and on low-level stratification in the atmosphere.

For quality assurance all measured data went through rigorous manual quality check including comparison of concurrent flask and in situ measurements and comparison with the tall tower measurements (see Sect. 2.3).

\subsection{PBL height data}

For the evaluation of the airborne measurements, the height of the planetary boundary layer data was retrieved from the Meteorological Archive and Retrieval System (MARS) database of the European Centre for Medium-Range Weather Forecasts (ECMWF). PBL height data were calculated by the deterministic model in forecast time steps with 3-h temporal resolution (Beljaars et al., 2001). Between the model time steps the PBL height was linearly interpolated as long as the PBL height increased with time during daytime. (During the late morning - early afternoon hours, when the flights were performed, no reduction in the PBL height was taken into account.) PBL height does not evolve linearly in the real world, so - having no better choice - the method applied gives only a rough estimation.

Taking into account the potentially significant $\mathrm{CO}_{2}$ concentration gradient around the top of the PBL and the uncertainty in the determination of the actual PBL height the upper $10 \%$ of the PBL was neglected in the calculation of the mean $\mathrm{PBL} \mathrm{CO} 2$ mole fraction.

\subsection{Validation of the airborne in situ measurements}

The airborne in situ measurements were validated by comparison with the flask air samples. For the comparison of the in situ $\mathrm{CO}_{2}$ measurements and the flask air samples a total of 110 samples were available. The intake of the flask sampling unit was collocated with that of the in situ analyzer. The flasks were flushed at each sampling elevation for $5 \mathrm{~min}$, while their pressurization took about $2 \mathrm{~min}$. For the comparison the synchronized 2-min averages from the in situ analyzer were used. The frequency distribution of the differences can be seen in Fig. 2. In Fig. 2 an extreme outlier of more than $5 \mu \mathrm{mol} \mathrm{mol}{ }^{-1}$ also appears. This sample with a flask sample value of $392.09 \mu \mathrm{mol} \mathrm{mol}^{-1}$ was taken at 10:58 UTC on 1 November 2006, at $200 \mathrm{~m}$ above the ground, when the 2-min average recorded by the in situ analyzer was $398.61 \mu \mathrm{mol} \mathrm{mol}^{-1}$ (corrected to $397.52 \mu \mathrm{mol} \mathrm{mol}^{-1}$ - see below). According to the ECMWF model the height of the planetary boundary layer was $144 \mathrm{~m}$ at 09:00 UTC, $84 \mathrm{~m}$ at 12:00 UTC and $226 \mathrm{~m}$ at 15:00 UTC, respectively. The unusual behavior of the boundary layer resulted in a highly inhomogeneous concentration distribution at the sampling elevation. The in situ analyzer recorded a range of mole fraction 


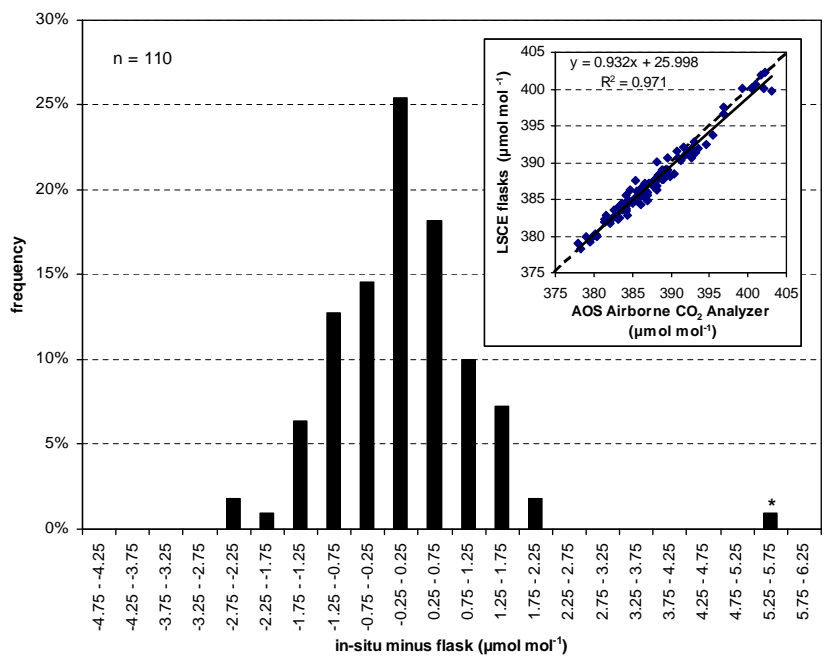

Fig. 2. Frequency distribution of the $\mathrm{CO}_{2}$ mole fraction differences between the flask air samples and the empirically corrected (see text) in situ measurements. The asterisk denotes the outlier discussed in the text. The inset shows the relation between the flask data and the uncorrected in situ data. Dashed line indicates the 1:1 relation.

from $392.4 \mu \mathrm{mol} \mathrm{mol}^{-1}$ to $405.7 \mu \mathrm{mol} \mathrm{mol}^{-1}$ during flushing and sampling by the flask sampler unit. A comparable fluctuation was measured at the top of the tower during the same period ( $115 \mathrm{~m}$ : $398-406 \mu \mathrm{mol} \mathrm{mol}^{-1}$ ), while the concentration recorded on board the aircraft above $250 \mathrm{~m}$ was steadily $392-393 \mu \mathrm{mol} \mathrm{mol}^{-1}$. The exact time of sampling cannot be determined as the flasks are gradually pressurized, which means a gradually decreasing filling stream (Chen et al., 2012), and the manually operated sampling unit was not exactly synchronized with the autonomous system clock of the in situ analyzer. Under such conditions, the observed difference of $5.4 \mu \mathrm{mol} \mathrm{mol}^{-1}$ between the flask value and the in situ observation may be simply the result of the non-exact synchronization of the measurements.

Rejecting this extreme outlier, the average deviation between the flask measurements and the in situ ones is $0.34 \pm 0.95 \mu \mathrm{mol} \mathrm{mol}^{-1}( \pm 1 \sigma$ standard deviation, here and thereafter in the paper) giving the higher values by the in situ measurements. The bias does not show any temporal variation or elevation-dependence, but it statistically significantly $(p<0.05)$ increases with the mole fraction. As the standards used for the in situ measurements and those for the analyses of the air samples are traceable to the same primary scale, and they were also intercompared, the cause of the concentrationdependent bias has remained unresolved. A possible cause is the non-linearity of the in situ analyzer not handled properly by the two-point calibration and by the internal software of the instrument, but the hypothesis could not be tested. For the consistency of the data used in this paper we have applied an empirical linear correction to the in situ airborne

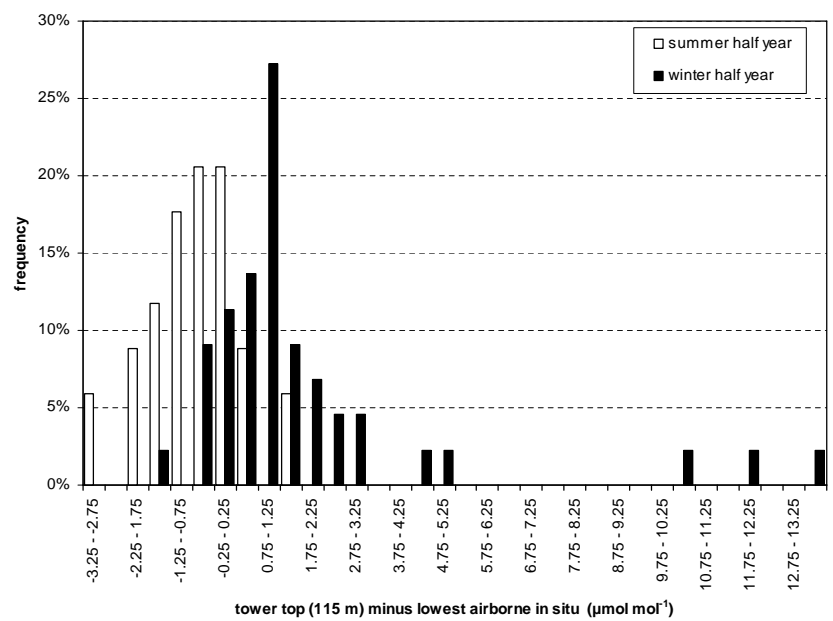

Fig. 3. Frequency distribution of the $\mathrm{CO}_{2}$ mole fraction differences between top of the tower and the lowest airborne in situ measurement elevation in the summer (April-September) and winter (October-March) half years.

measurements to eliminate the bias and the concentration dependence.

The relatively large scatter of the in situ - flask $\mathrm{CO}_{2}$ difference can be explained by the unavoidable temporal asynchrony of the measurements, and by the real world spatial/temporal heterogeneity of the concentration field. The system noise of the airborne analyzer operated under harsh environmental conditions (fast and significant temperature and pressure changes, mechanical vibration, etc.) is also likely higher than in laboratory environment as it was shown by Font et al. (2008) for an instrument of similar type. It is also observed that the standard deviation of the difference between the flasks and the in situ measurements is higher in the lower part of the atmosphere $\left(1.02 \mu \mathrm{mol} \mathrm{mol}^{-1}\right.$ below $1000 \mathrm{~m}$ versus $0.88 \mu \mathrm{mol} \mathrm{mol}^{-1}$ above $2000 \mathrm{~m}$ ), which probably results from the higher homogeneity of the upper layers.

As an additional test the results of the in situ airborne measurements at the lowest elevation were compared with the simultaneous $\mathrm{CO}_{2}$ measurements at the top of the tall tower ( $115 \mathrm{~m}$ above ground). In this test those measurements were involved when the lowest airborne measurement was performed below $250 \mathrm{~m}$ above ground and the height of the PBL was at least $400 \mathrm{~m}$. The frequency distribution of the tower top and airborne in situ measurement differences can be seen in Fig. 3, separately for the summer (April-September) and winter (October-March) half years. The distributions show remarkable discrepancy. In summer the tower top mole fraction tends to be lower than that at the lowest airborne elevation $\left(-0.67 \pm 1.04 \mu \mathrm{mol} \mathrm{mol}^{-1}\right)$, while the winter difference is just the opposite $\left(+1.79 \pm 3.06 \mu \mathrm{mol} \mathrm{mol}^{-1}\right)$. In winter we see three extreme outliers when the tower top - airborne difference is larger than $10 \mu \mathrm{mol} \mathrm{mol}^{-1}$. These cases were individually checked. 
On 2 March 2006 (deviation is $13.29 \mu \mathrm{mol} \mathrm{mol}^{-1}$ ) the $\mathrm{CO}_{2}$ mole fraction at $240 \mathrm{~m}$ above the ground was $390.7 \mu \mathrm{mol} \mathrm{mol}^{-1}$, while it varied between 394 and $406 \mu \mathrm{mol} \mathrm{mol}^{-1}$ at the top of the tower around the time of the airborne measurements. This high variation close to the surface indicate some sort of local pollution. The situation was similar on 12 November 2006 (deviation is $10.59 \mu \mathrm{mol} \mathrm{mol}^{-1}$ ) when the airborn in situ measurement (validated by a flask sample in this case) indicated $386.5 \mu \mathrm{mol} \mathrm{mol}^{-1}$, while the range at the tower top was 394$402 \mu \mathrm{mol} \mathrm{mol}^{-1}$. These flights were performed relatively early on the day (9:36 and 11:18 local standard time [LST], respectively) because of weather conditions and logistics. The third case $\left(11.85 \mu \mathrm{mol} \mathrm{mol}^{-1}\right.$ difference on 18 January 2009) was different. The ascending profile was started over the tower at $230 \mathrm{~m}$ above the ground at 14:06 LST indicating $403.4 \mu \mathrm{mol} \mathrm{mol}^{-1}$, while the descending profile ended at as low as $140 \mathrm{~m}$ at $14: 44 \mathrm{LST}$ showed $415.6 \mu \mathrm{mol} \mathrm{mol}^{-1}$. The tower top recorded a steady $415-416 \mu \mathrm{mol} \mathrm{mol}^{-1}$ mole fraction during the flight. The measurement indicate a strong substratification within the $720 \mathrm{~m}$ high planetary boundary layer.

Omitting the three outliers discussed above the winter tower top - airborne difference gets reduced to $+1.05 \pm 1.32 \mu \mathrm{mol} \mathrm{mol}^{-1}$. Giving equal weight to the summer and winter averages the average bias is $+0.19 \mu \mathrm{mol} \mathrm{mol}^{-1}$. The remaining difference between the summer and winter half year is natural, it is resulted by the annual variation of the net $\mathrm{CO}_{2}$ flux at the surface, which influences more the surface layer than the layers above. See also Sect. 3.1.

The study of the mole fraction difference between the top of the tower and the lowest airborne measurement elevation warns the researchers about the extreme temporal/spatial heterogeneity occasionally occurring in the lowest atmosphere, especially under winter continental conditions. It also calls the attention to the proper choice of the measurement time. Although, the result of the comparison is not a direct evidence but the close-to-zero deviation is convincing not having a systematic bias between the different measurements, and suggest the comparability of the measurements from the three different sources (airborn in situ, flask, tower based).

\section{Results}

\subsection{Estimation of the mean $\mathrm{PBL} \mathrm{CO}_{2}$ mole fraction using tall tower data}

One of the major sources of uncertainty in the representation of $\mathrm{CO}_{2}$ mole fractions by atmospheric transport models lies in the imperfect parametrisation of the vertical mixing through the planetary boundary layer. For this reason, the simulated mole fractions may have a large representativity error once compared to a single point measurement like at the top of a high tower. Ideally we could have a better model - data consistency by comparing the mean PBL mole frac- tions. If the PBL were perfectly mixed, as it is often assumed, then ground based measurements would provide exact information on the average mole fraction in the PBL. The continuous $\mathrm{CO}_{2}$ mole fraction measurements at Hegyhátsál tall tower site and the occasional airborne vertical profile measurements above the tower allow us to estimate how well a measurement made on the top of a $115 \mathrm{~m}$ tall tower can characterize the average PBL mole fraction. As a frequent airborne measurement program is rather costly relative to the operation of a tall tower site it is important to know how much information/accuracy is lost if the $\mathrm{CO}_{2}$ mole fraction in the PBL is estimated only on the basis of tall tower measurements.

For the estimation of the mean $\mathrm{CO}_{2}$ mole fraction in the planetary boundary layer 133 combined airborne/tower vertical profiles measured on 71 days between late morning and early afternoon were available. Three profiles on two winter days were rejected because an extreme concentration difference was observed between the top of the tower (115 $\mathrm{m}$ above the ground) and the lowest level of the aircraft measurements (about $200 \mathrm{~m}$ above the ground). Inspection of the weather conditions on those days suggests that low level inversions were formed within the PBL, below which local emission might accumulate creating very strong vertical $\mathrm{CO}_{2}$ gradient or local pollution might reach the monitoring site.

Aircraft profiles were traced from their lowest points around $200 \mathrm{~m}$ above the ground, up to the top of the PBL provided by the ECMWF model. The in situ $\mathrm{CO}_{2}$ measurements with a temporal resolution of $1 \mathrm{~s}$ were first block-averaged with $50 \mathrm{~m}$ vertical resolution to avoid unequal weighting of the different atmospheric layers in those cases when the aircraft leveled for several minutes in order to take flask air samples at a constant altitude. Between the top of the tower and the lowest aircraft measurements the mole fraction was linearly interpolated. The tower measurements were timeaveraged for the period of the aircraft profile measurements, usually for 15-20 min. To avoid the distorting effect of uneven temporal distribution of the measurements through the year, the $\mathrm{CO}_{2}$ differences between the mean PBL mole fraction and the one measured on the tower were calculated and averaged for each month separately.

In annual average, the $\mathrm{CO}_{2}$ mole fraction measured at the top of the tall tower at Hegyhátsál (115 m above the ground) overestimates the PBL mean $\mathrm{CO}_{2}$ mole fraction by $0.35 \mu \mathrm{mol} \mathrm{mol}^{-1}$. This annual average value of the bias between tower and aircraft masks changes in the difference between the summer and winter seasons. In the summer half year (April-September) the top of the tower underestimates the PBL mean $\mathrm{CO}_{2}$ by $0.27-0.85 \mu \mathrm{mol} \mathrm{mol}^{-1}$. It reflects intense $\mathrm{CO}_{2}$ uptake by the vegetation at the surface. By contrast, in the winter half year (October-March), $\mathrm{CO}_{2}$ measured on top of the tower is higher than the mean $\mathrm{CO}_{2}$ mole fraction in the PBL by $0.66-1.83 \mu \mathrm{mol} \mathrm{mol}^{-1}$ due to net surface $\mathrm{CO}_{2}$ emission by soil, vegetation and possible anthropogenic sources. The impact of the surface fluxes on the 

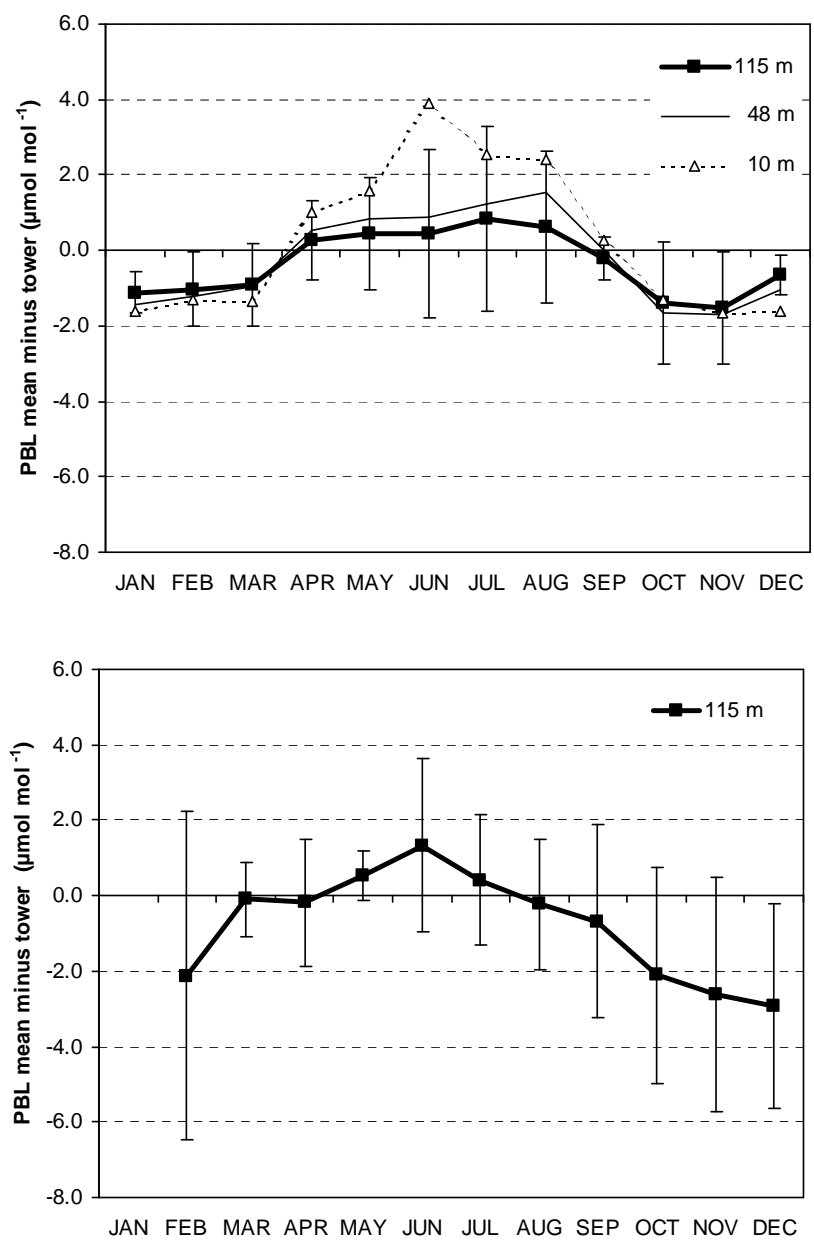

Fig. 4. Top panel: Seasonal variation of the average deviation between the PBL mean $\mathrm{CO}_{2}$ mole fraction calculated from the in situ aircraft measurements plus tower measurements and that measured at $115 \mathrm{~m}, 48 \mathrm{~m}$ as well as at $10 \mathrm{~m}$ elevations above the ground at Hegyhátsál tall tower site. Bottom panel: Seasonal variation of the average deviation between the PBL mean $\mathrm{CO}_{2}$ mole fraction calculated from the aircraft flask air samples plus tower measurements and that measured at $115 \mathrm{~m}$ on the tall tower at Hegyhátsál. No data is presented for January because of the low number $(n=2)$ of samples. In the top panel $\pm 1 \sigma$ (standard deviation) is given only for $115 \mathrm{~m}$ for the clarity of the figure.

tower/PBL difference is stronger in wintertime due to the less vigorous vertical atmospheric mixing. The seasonal variation of the PBL-mean minus tower measurement difference is presented in the top panel of Fig. 4, based on the monthly averages. For illustration, the figure also shows how accurately a lower tower ( $48 \mathrm{~m}$ in this case) or a near-ground monitoring elevation $(10 \mathrm{~m})$ would estimate the PBL mean $\mathrm{CO}_{2}$ mole fraction. It can be seen that the bias increases significantly if a shorter tower is used as a proxy for the mean $\mathrm{PBL} \mathrm{CO}_{2}$ mole fraction. The lower the tower level, the larger are the negative (positve) bias in summer (winter) between tower and the PBL-mean. It should also be noted that the lower the tower, the more site-specific can be this result due to the increasing influence of the local $\mathrm{CO}_{2}$ fluxes and transport effects (e.g. different surface roughness, etc.).

As an alternative, the mean $\mathrm{CO}_{2}$ mole fraction in the PBL can also be estimated combining the flask air samples and the tower measurements. In this case we have less data, coarser vertical resolution for the profile. Especially in the winter seasons, several flights had to be excluded from the analysis because even the lowest sampling level was above the top of the planetary boundary layer. There were a total of 66 flights when at least a single aircraft flask air sample was taken within the PBL and tower measurements were also available. For calculating the mean $\mathrm{CO}_{2}$ mole fraction in the PBL, the measured mole fractions were linearly interpolated between the sampling levels (along the tower, between the top of the tower and the lowest aircraft sampling level, and between the flask sampling levels in the PBL). As a significant mole fraction change was frequently observed across the top of the boundary layer, above the uppermost aircraft sampling level within the PBL up to the top of the PBL a constant mole fraction was assumed. The seasonal variation of the PBL-mean (from flasks) minus tower-top $\mathrm{CO}_{2}$ difference is presented in the bottom panel of Fig. 4 based on the monthly averages. As the number of flights was significantly lower in this case than in the case of the in situ profile measurements, the picture is not as clear as above, but the main result appears to be robust: in the summer half year (April-September) the top of the tower underestimates the PBL mean $\mathrm{CO}_{2}$ determined from flask air samples, while it overestimates that in the winter half year (October-March). However, the seasonal amplitude of the PBL-mean minus tower-top difference is higher than when the same quantity was calculated using the in situ aircraft measurements. The reason for this is that linear interpolation of flask $\mathrm{CO}_{2}$ values usually overestimas the "true" mole fraction along the profile in winter, while it underestimates it in summer as it is illustrated by Fig. 5. It was already discussed by Bakwin et al. (2003) that the mean PBL mole fraction usually cannot be estimated free of bias from airborne flask air samples from a small number of levels.

There were 7 winter flights and 8 summer flights during which both in situ measurements and flask air sampling were performed, as well as the other conditions (PBL height, availability of tower measurements) allowed the direct comparison of the PBL mean mole fractions calculated from the in situ measurements and from interpolated values of flask air samples. Indeed, in accordance with the reasoning above, in winter the flask samples overestimate the PBL mean mole fraction by $0.52 \pm 0.87 \mu \mathrm{mol} \mathrm{mol}^{-1}$, while they slightly underestimate it in summer $\left(0.22 \pm 0.80 \mu \mathrm{mol} \mathrm{mol}^{-1}\right)$, compared to the in situ measurements. 


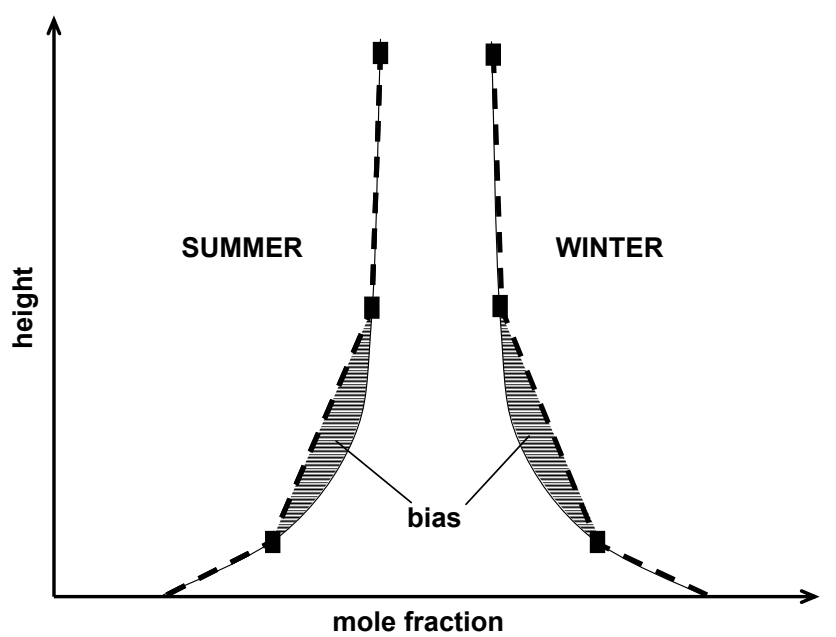

Fig. 5. Schematic representation of winter and summer differences between the vertical mole fraction profiles measured in situ (thin lines) and that reconstructed from flask air sample measurements (black blocks) using linear interpolation (thick dashed lines). In summer the linear interpolation between the sampling elevations causes negative bias in the calculated PBL mean mole fraction relative to the actual one, while in winter the bias is positive (see the shaded areas).

\subsection{Seasonal variation of $\mathrm{CO}_{2}$ mole fraction at different elevations}

For the determination of the mean seasonal cycle of $\mathrm{CO}_{2}$ mole fraction throughout the PBL and in the lower free troposphere, a total of 192 profiles were available combining the flask samples and in situ measurements. The seasonal cycles were calculated at different altitudes from the data series detrended and smoothed by means of CCGCRV data evaluation software developed at NOAA (Thoning et al., 1989). For the calculations, both the flask and the in situ measurements were layer-averaged for $500-1500 \mathrm{~m}, 1500-2500 \mathrm{~m}$, and $>2500 \mathrm{~m}$ above ground. In the case of the flask air samples, samples taken at the border of two layers were taken into account in both layers with half weight. The average seasonal cycles were also calculated for the top of the tall tower $(115 \mathrm{~m})$ and for the lowest measurement level $(10 \mathrm{~m})$ using the early afternoon mean mole fraction data from the days of aircraft measurements. The mean seasonal cycles are given in Fig. 6.

Only in 5 of the 192 cases $(2.6 \%)$ the PBL was higher than $2500 \mathrm{~m}$, therefore, we assumed that the uppermost layer studied $(>2500 \mathrm{~m})$ represents the lower free troposphere. In more than one third of the cases, the PBL height lay between $1500 \mathrm{~m}$ and $2500 \mathrm{~m}$, and in half of the cases it fell into the layer $500-1500 \mathrm{~m}$ (see also the PBL height statistics in Fig. 7). In 18 cases (9.4\%) the PBL was so shallow $(<500 \mathrm{~m}$, dominantly in winter) that no PBL mole fraction data was available for the present analysis.

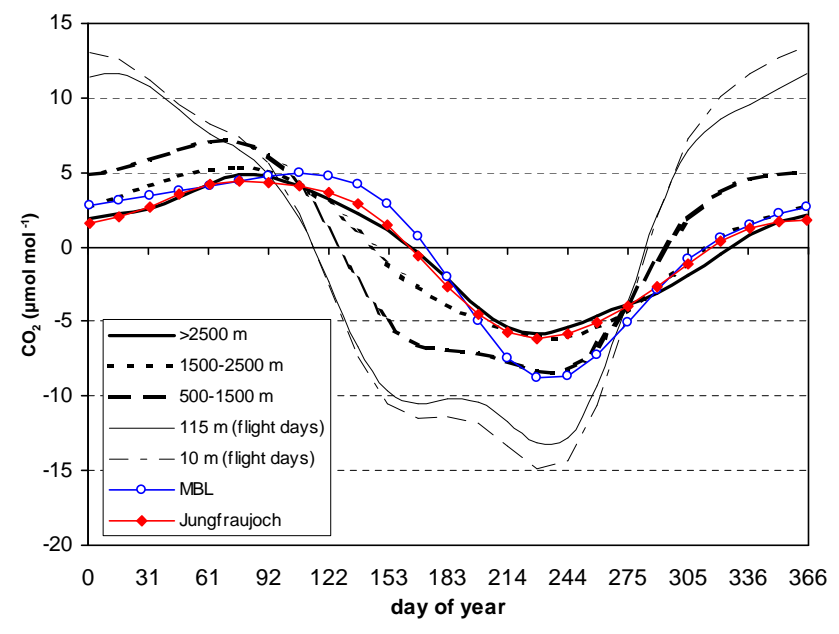

Fig. 6. Mean seasonal cycle (relative to the corresponding annual average) at different elevations above the ground at Hegyhátsál, at Jungfraujoch high alpine station and in the modeled marine boundary layer (MBL).

As the dominant sources and the sinks of carbon dioxide are located at the surface, the peak-to-peak amplitude of the seasonal cycle attenuates with height. While this amplitude is as high as $28.5 \mu \mathrm{mol} \mathrm{mol}^{-1}$ at $10 \mathrm{~m}$ above the ground it is only $10.7 \mu \mathrm{mol} \mathrm{mol}^{-1}$ above $2500 \mathrm{~m}$, up to the top of the measurements (approx. $3000 \mathrm{~m}$ ). The phase of the seasonal cycle is significantly different depending on the elevation. Although the vegetation becomes a net $\mathrm{CO}_{2}$ sink only in mid/late March, early April in this region (Haszpra et al., 2005), the mole fraction in the surface layer has its maximum value in late December, early January, and then begins to decrease. The non-obvious shape of the seasonal cycle observed can be explained by the regional feature of the vertical mixing of the atmosphere as it is discussed by Haszpra et al. (2008) in details. From January, following the slowly increasing insolation after the winter solstice, vertical mixing is quickly getting more vigorous, so that more LFT air with lower $\mathrm{CO}_{2}$ values gets entrained into the $\mathrm{CO}_{2}$-enriched PBL. This process overcompensates the contribution of surface that is still a net $\mathrm{CO}_{2}$ source in that time of the year. This process also contributes to the increase in the mole fraction in the higher atmospheric layers at this time of the year.

The decreasing mole fraction in the surface layer also gradually influences the upper layers of the atmosphere through mixing. However, at higher elevations, large-scale advection of air masses affected by remote $\mathrm{CO}_{2}$ sources and sinks likely dominates the seasonal cycle. In the 500$1500 \mathrm{~m}$ layer the maximum concentration is observed around 10 March on average. Decrease of the mole fraction begins a week later in the 1500-2500 m layer and two weeks later (around $25 \mathrm{March}$ ) above $2500 \mathrm{~m}$. Even in the layer of 2500$3000 \mathrm{~m}$, almost exclusively located in the LFT, the maximum in the $\mathrm{CO}_{2}$ seasonal cycle is two weeks ahead of that of 

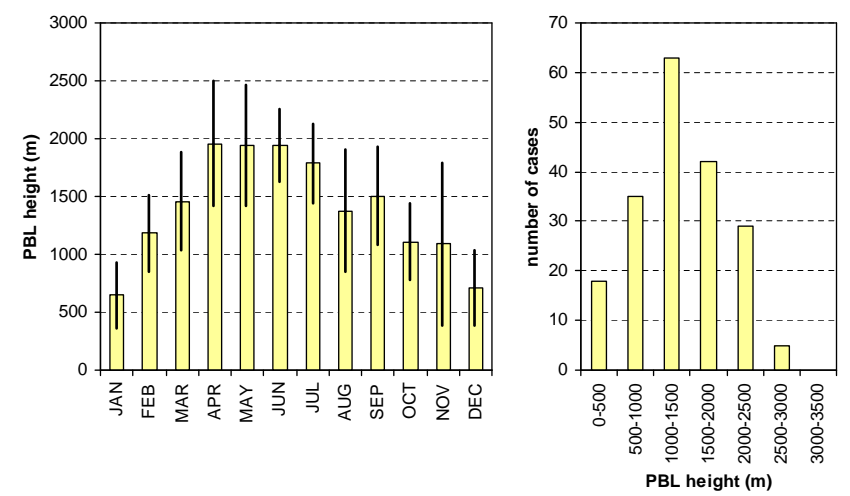

Fig. 7. PBL height statistics for the times of the aircraft measurements. Error bars: $\pm 1 \sigma$ (st. dev.).

the marine boundary layer reference (MBL) modeled for the geographical latitude of Hegyhátsál (GLOBALVIEW-CO2, 2010). This earlier timing of maximum $\mathrm{CO}_{2}$ value inside the continent indicates the governing role of the continental vegetation in the seasonal cycle; spring $\mathrm{CO}_{2}$ uptake by European ecosystems affecting first $\mathrm{CO}_{2}$ mole fractions at continental sites, and only later marine boundary layer sites. The seasonal minimum in $\mathrm{CO}_{2}$ mole fraction can be observed approximately in the same time (around 20 August) in all layers. This synchronisation of the timing of minimum $\mathrm{CO}_{2}$ with height may be explained by convective mixing in the PBL and by thick PBL in summer. Due to the low number of the measurements and the corresponding uncertainty in the statistical analysis the above numbers can only be considered as rough estimations, however, they still characterize the processes qualitatively.

For illustration Fig. 6 also presents the mean seasonal cycle at Jungfraujoch European high alpine monitoring station $\left(46^{\circ} 33^{\prime} \mathrm{N}, 7^{\circ} 59^{\prime} \mathrm{E}, 3580 \mathrm{~m}\right.$ a.s.l.) operated by the Climate and Environmental Physics Division of the Physics Institute at University of Bern. Here the maximum $\mathrm{CO}_{2}$ mole fraction can be observed around 20 March, while the minimum is recorded around 20 August, just like at Hegyhátsál. Taking into account that data were available from Jungfraujoch for a different period (2005-2011 vs. 2001-2008) and the mean seasonal cycle were estimated only on the basis of a limited number of measurements over Hegyhátsál, the timing of the annual maximum can be considered as very similar. The annual amplitude at this high mountain station is $10.6 \mu \mathrm{mol} \mathrm{mol}^{-1}$, practically identical with that at 2500 $3000 \mathrm{~m}$ above Hegyhátsál $\left(10.7 \mu \mathrm{mol} \mathrm{mol}^{-1}\right)$.

The smoothed seasonal cycles of $\mathrm{CO}_{2}$ mole fraction over the tower presented here should be considered with some caution. Aircraft measurements were possible only under weather conditions safe for flying. It may cause "fair weather" bias in the data series, that is, "fair weather" conditions may be overrepresented. To partially check this effect Fig. 8 shows the average seasonal cycle for the top of

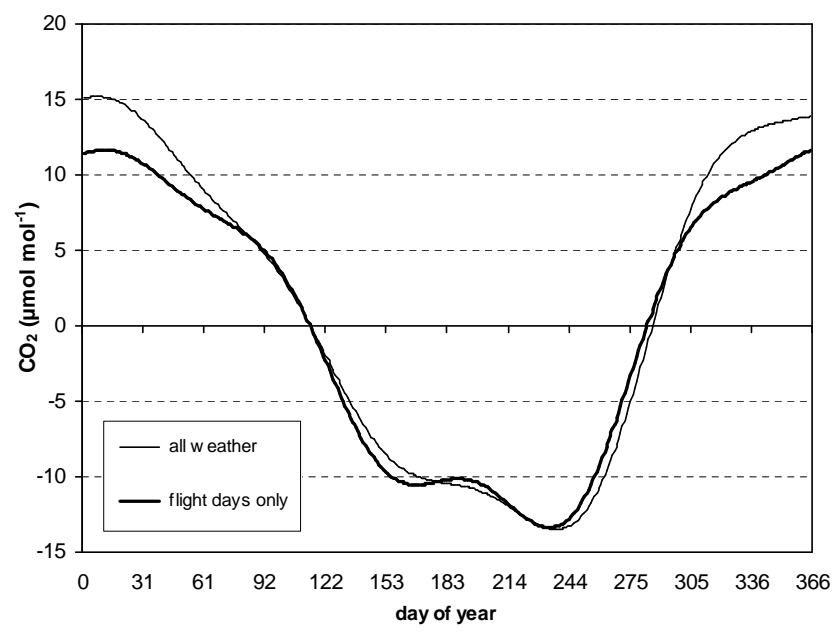

Fig. 8. Mean $\mathrm{CO}_{2}$ seasonal cycles at the top of the tower $(115 \mathrm{~m}$ above ground) calculated from all daily (early afternoon) data ("all weather") and from those days when aircraft measurements were performed ("flight days") relative to the annual average of the "flight days".

the tower $(115 \mathrm{~m})$ using data from each day in the period of 2002-2008 and that based only on those days when aircraft measurements were performed. (This latter curve is also presented in Fig. 6.) It can be seen that the "all weather" seasonal cycle shows higher annual amplitude than that based on the "fair weather" subset of the data. The two seasonal cycles show statistically significant $(p<0.005)$ deviation in winter. During wintertime, limited vertical mixing usually covaries with foggy/hazy conditions in the region of the tower that do not allow flying. During these episodes of limited vertical mixing $\mathrm{CO}_{2}$ accumulates in the shallow planetary boundary layer sampled by the tower as it has its sources at the ground. Including these foggy/hazy days into the $\mathrm{CO}_{2}$ seasonal cycle estimation results in higher average mole fraction for winter compared to when only the fair weather days were considered. The "fair weather" bias thus results in an underestimation of $\mathrm{CO}_{2}$ mole fraction by $3.7 \mu \mathrm{mol} \mathrm{mol}^{-1}$ in winter. In summer, most of the time, weather conditions do not obstruct flying. We calculated a statistically insignificant $(p<0.005)$ difference between the "flight day" and the "all weather" $\mathrm{CO}_{2}$ measurements, which might be the consequence of the limited number and uneven temporal distribution of the flight days. This test cannot estimate the magnitude of the "fair weather" bias in the upper layers. For this purpose time series of vertical profiles from 3-dimensional transport models would be necessary. However, it can be assumed that "fair weather" bias in summer is also negligible in the upper layers due to the intensive mixing of the planetary boundary layer. 


\section{Summary and conclusions}

On the basis of aircraft and tall tower measurements at and above Hegyhátsál, Hungary, we estimated how accurately the mean $\mathrm{CO}_{2}$ mole fraction in the PBL can be estimated from tall tower measurements and what are the differences in the seasonal cycles in the $\mathrm{CO}_{2}$ mole fraction at different elevations from the ground, through the PBL and up to the lower free troposphere. It was found that measurements at $115 \mathrm{~m}$ above the ground (the top of the tower) estimated the PBL mean $\mathrm{CO}_{2}$ mole fraction with a mean bias of only $+0.35 \pm 0.85 \mu \mathrm{mol} \mathrm{mol}^{-1}$ on annual average. During the summer season (April-September), the intensive uptake of carbon dioxide by the vegetation maintains a negative vertical $\mathrm{CO}_{2}$ gradient towards the ground in spite of the intense (convective) vertical mixing of the PBL. Consequently, the towertop measurements underestimate the PBL mean $\mathrm{CO}_{2}$ mole fraction only by a small amount: $0.27-0.85 \mu \mathrm{mol} \mathrm{mol}^{-1}$ at $115 \mathrm{~m}$ above the ground. Such a small bias might be tolerable by atmospheric $\mathrm{CO}_{2}$ transport models that can only best simulate $\mathrm{CO}_{2}$ value averaged in the well-mixed PBL. As the spatial representativeness of $\mathrm{CO}_{2}$ mole fraction measured on a tall tower over a flat and rather uniform terrain is fairly high, this bias estimation might be valid for most towers located in the vegetated temperate zone. The shorter the tower, the higher the bias between the tower-top measurements and the PBL mean, and the greater the influence of the local vegetation or fossil fuel fluxes. During the winter season (OctoberMarch), the shape of the vertical profile of the $\mathrm{CO}_{2}$ mole fraction is just the opposite of that in summer. Usually the concentration is decreasing with elevation because the surface is a net $\mathrm{CO}_{2}$ source this time of the year and mixing is limited. The estimation of the mean PBL mole fraction from the measurements performed at the top of the tower $(115 \mathrm{~m})$ might be biased by $0.66-1.83 \mu \mathrm{mol} \mathrm{mol}^{-1}$ during fair weather conditions in winter, when aircraft profiles could be taken. In foggy, hazy winter weather situations, usually characterized by reduced vertical mixing and not sampled by the aircraft measurements, the positive bias of the tower-top measurements may be even higher. This "fair weather bias" is negligible in summer.

In accordance with the conclusion of Bakwin et al. (2003) our study suggests that few flask air samples are not always sufficient to represent the mean PBL value of the $\mathrm{CO}_{2}$ mole fraction, especially in winter when occasionally only 1-3 flask samples were taken in the PBL. The estimation of the mean PBL mole fraction by interpolation of flask air sample values may deviate from the real one (as determined by in situ measurements) by as much as $2 \mu \mathrm{mol} \mathrm{mol}^{-1}$ on average.

According to the measurements at Hegyhátsál the seasonal cycle in the mole fraction is reduced in amplitude and delayed in phase with increasing elevation. The seasonal amplitude of $\mathrm{CO}_{2}$ mole fraction in the lower free troposphere represented by the measurements above $2500 \mathrm{~m}$ falls to the third of that at $10 \mathrm{~m}$ above the ground. While the maximum
$\mathrm{CO}_{2}$ value in the surface layer can be observed late December - early January, it is recorded in the layer $500-1500 \mathrm{~m}$ only in early March. The timing of the maximum in the layer $1500-2500 \mathrm{~m}$ is further delayed by approximately a week, and by another week in the layer $2500-3000 \mathrm{~m}$. The evolution of the seasonal cycle at different elevations results from the interaction between the local/regional fluxes and mixing, and large-scale circulation. The maximum of $\mathrm{CO}_{2}$ amount in the composite marine boundary layer curve at the latitude of our site is reached only by mid-April. Therefore, the MBL mole fractions cannot substitute the free tropospheric ones over continents. A similar conclusion was drawn by Gerbig et al. (2003) based on the measurements over North America. Nevertheless, the calculated monthly smoothed $\mathrm{CO}_{2}$ seasonal cycles should be considered with some caution because of the "fair weather bias" discussed above. It has negligible or no effect in summer but may influence not only the lower elevations in winter. The present and further evaluations of the joint tower - aircraft measurements have the potential to give better estimations for the PBL and the lower free troposphere.

Data used in this study are available at the CarboEurope-IP database (http://ce-atmosphere.lsce.ipsl.fr/ DATA_RELEASE/index.php) and from the corresponding author.

Acknowledgements. The authors thank Martin Simon (Air Taxi Ltd.), pilot of the aircrafts hired for the airborne measurements, and his crew for taking the flask air samples and operating the in situ analyzer during the flights. The authors also thank the valuable advice of Anna Font and Josep-Anton Murguí (Inst. Catalá de Ciències del Clima, Spain), as well as that of Huilin Chen and Christoph Gerbig (Max Planck Institute for Biogeochemistry, Germany). The authors thank Kirk Thoning (NOAA ESRL, U.S.A.) for the CCGCRV data analysis software used in this study and Frederic Chevallier (LSCE, France) for his contribution. The authors thank the responsible staff of the Climate and Environmental Physics Division of the Physics Institute at the University of Bern (S. van der Laan, I. van der Laan-Luijkx, M. Leuenberger) for kindly providing the $\mathrm{CO}_{2}$ data measured at Jungfraujoch high alpine monitoring station (data downloaded through the WMO World Data Centre for Greenhouse Gases on 21 August 2012). The monitoring program at and above Hegyhátsál tall tower site was supported by the 5th and 6th R\&D Framework Programmes of the European Commission (AEROCARB - EVK2-CT-1999-00013, CarboEurope-IP - GOCE-CT-2003-505572, IMECC - RII3 026188), by the Hungarian Ministry of Economy and Transport (GVOP-3.2.1.-2004-04-0107/3.0), as well as by the Hungarian Scientific Research Fund and the National Development Agency (OTKA T042941, KTIA-OTKA CK77550). The project was also co-financed by the European Social Fund (grant agreement no. TAMOP 4.2.1/B-09/1/KMR-2010-0003).

Edited by: M. K. Dubey 


\section{References}

Acevedo, O. C., da Silva, R., Fitzjarrald, D. R., Moraes, O. L. L., Sakai, R. K., and Czikowsky, M. J.: Nocturnal vertical $\mathrm{CO}_{2}$ accumulation in two Amazonian ecosystems, J. Geophys. Res., 113G, G00B04, doi:10.1029/2007jg000612, 2008.

Bakwin, P. S., Tans, P. P., Zhao, C., Ussler, W. I., and Quesnell, E.: Measurements of carbon dioxide on a very tall tower, Tellus, 47B, 535-549, 1995.

Bakwin, P. S., Tans, P. P., Stephens, B. B., Wofsy, S. C., Gerbig, C., and Grainger, A.: Strategies for measurement of atmospheric column means of carbon dioxide from aircraft using discrete sampling., J. Geophys. Res., 108, 4514, doi:10.1029/2002JD003306, 2003.

Bakwin, P. S., Davis, K. J., Yi, C., Wofsy, S. C., Munger, J. W., Haszpra, L., and Barcza, Z.: Regional carbon dioxide fluxes from mixing ratio data, Tellus, 56B, 301-311, doi:10.1111/j.16000889.2004.00111.x, 2004.

Beljaars, A., Jakob, C., and Morcrette, J.-J.: New physics parameters in the MARS archive, ECMWF Newsletter, 90, 17-21, 2001.

Chen, H., Winderlich, J., Gerbig, C., Katrynski, K., Jordan, A., and Heimann, M.: Validation of routine continuous airborne $\mathrm{CO}_{2}$ observations near the Bialystok Tall Tower, Atmos. Meas. Tech., 5, 873-889, doi:10.5194/amt-5-873-2012, 2012.

Crevoisier, C., Sweeney, C., Gloor, M., Sarmiento, J. L., and Tans, P. P.: Regional US carbon sinks from threedimensional atmospheric $\mathrm{CO}_{2}$ sampling, PNAS, 107, 1834818353, doi:10.1073/pnas.0900062107, 2010.

Engelen, R. J. and McNally, A. P.: Estimating atmospheric $\mathrm{CO}_{2}$ from advanced infrared satellite radiances within an operational four-dimensional variational (4D-Var) data assimilation system: Results and validation, J. Geophys. Res., 110, D18305, doi:10.1029/2005JD005982, 2005.

Engelen, R. J., Serrar, S., and Chevallier, F.: Four-dimensional data assimilation of atmospheric $\mathrm{CO}_{2}$ using AIRS observations, J. Geophys. Res., 114D, D03303, doi:10.1029/2008JD010739, 2009.

Feng, L., Palmer, P. I., Yang, Y., Yantosca, R. M., Kawa, S. R., Paris, J. D., Matsueda, H., and Machida, T.: Evaluating a 3-D transport model of atmospheric $\mathrm{CO}_{2}$ using ground-based, aircraft, and space-borne data, Atmos. Chem. Phys., 11, 27892803, doi:10.5194/acp-11-2789-2011, 2011.

Font, A., Morguí, J. A., and Rodó, X.: Atmospheric $\mathrm{CO}_{2}$ in situ measurements: Two examples of Crown Design flights in NE Spain, J. Geophys. Res., 113D, D12308, doi:10.1029/2007JD009111, 2008.

Geels, C., Gloor, M., Ciais, P., Bousquet, P., Peylin, P., Vermeulen, A. T., Dargaville, R., Aalto, T., Brandt, J., Christensen, J. H., Frohn, L. M., Haszpra, L., Karstens, U., Rödenbeck, C., Ramonet, M., Carboni, G., and Santaguida, R.: Comparing atmospheric transport models for future regional inversions over Europe - Part-1: mapping the atmospheric $\mathrm{CO}_{2}$ signals, Atmos. Chem. Phys., 7, 3461-3479, doi:10.5194/acp-7-3461-2007, 2007.

Gerbig, C., Lin, J. C., Wofsy, S. C., Daube, B. C., Andrews, A. E., Stephens, B. B., Bakwin, P. S., and Grainger, C. A.: Toward constraining regional-scale fluxes of $\mathrm{CO}_{2}$ with atmospheric observations over a continent: 1 . Observed spatial variability from airborne platforms, J. Geophys. Res., 108, 4756, doi:10.1029/2002JD003018, 2003.
GLOBALVIEW-CO2: Cooperative Atmospheric Data Integration Project - Carbon Dioxide, CD-ROM, NOAA ESRL, Boulder, Colorado [Also available on Internet via anonymous FTP to ftp.cmdl.noaa.gov, Path: ccg/co2/GLOBALVIEW], 2010.

Gloor, M., Bakwin, P., Hurst, D., Lock, L., Draxler, R., and Tans, P.: What is the concentration footprint of a tall tower? J. Geophys. Res., 106, 17831-17840, 2001.

Haszpra, L., Barcza, Z., Bakwin, P. S., Berger, B. W., Davis, K. J., and Weidinger, T.: Measuring system for the long-term monitoring of biosphere/atmosphere exchange of carbon dioxide, J. Geophys. Res., 106, 3057-3070, 2001.

Haszpra, L., Barcza, Z., Davis, K. J., and Tarczay, K.: Long term tall tower carbon dioxide flux monitoring over an area of mixed vegetation, Agr. Forest Meteorol., 132, 58-77, 2005.

Haszpra, L., Barcza, Z., Hidy, D., Szilágyi, I., Dlugokencky, E., and Tans, P.: Trends and temporal variations of major greenhouse gases at a rural site in Central Europe, Atmos. Environ., 42, 8707-8716, 2008.

Haszpra, L., Barcza, Z., and Szilágyi, I.: Atmospheric trends and fluctuations - History and sites of atmospheric greenhouse gas monitoring in Hungary, in: Atmospheric greenhouse gases: The Hungarian perspective, Springer, Dordrecht-HeidelbergLondon-New York, 9-23, 2010.

Manning, A. C., Jordan, A., Levin, I., Schmidt, M., Neubert, R. E. M., Etchells, A., Steinberg, B., Ciais, P., Aalto, T., Apadula, F., Brand, W. A., Delmotte, M., Giorgio di Sarra, A., Hall, B., Haszpra, L., Huang, L., Kitzis, D., van der Laan, S., Langenfelds, R. L., Leuenberger, M., Lindroth, A., Machida, T., Meinhardt, F., Moncrieff, J., Morguí, J. A., Necki, J., Patecki, M., Popa, E., Ries, L., Rozanski, K., Santaguida, R., Steele, L. P., Strom, J., Tohjima, Y., Thompson, R. L., Vermeulen, A., Vogel, F., and Worth, D.: Final report on CarboEurope "Cucumber" intercomparison programme, available at: http://cucumbers.webapp2.uea. ac.uk/documents/CucumberFinalReport_Final.pdf, 2009.

Patra, P. K., Niwa, Y., Schuck, T. J., Brenninkmeijer, C. A. M., Machida, T., Matsueda, H., and Sawa, Y.: Carbon balance of South Asia constrained by passenger aircraft $\mathrm{CO}_{2}$ measurements, Atmos. Chem. Phys., 11, 4163-4175, doi:10.5194/acp11-4163-2011, 2011.

Peters, W., Jacobson, A. R., Sweeney, C., Andrews, A. E., Conway, T. J., Masarie, K., Miller, J. B., Bruhwiler, L. M. P., Pétron, G., Hirsch, A. I., Worthy, D. E. J., Werf, G. R. v. d., Randerson, J. T., Wennberg, P. O., Krol, M. C., and Tans, P. P.: An atmospheric perspective on North American carbon dioxide exchange: CarbonTracker, PNAS, 104, 18925-18930, 2007.

Pickett-Heaps, C. A., Rayner, P. J., Law, R. M., Ciais, P., Patra, P. K., Bousquet, P., Peylin, P., Maksyutov, S., Marshall, J., Rödenbeck, C., Langenfelds, R. L., Steele, L. P., Francey, R. J., Tans, P., and Sweeney, C.: Atmospheric $\mathrm{CO}_{2}$ inversion validation using vertical profile measurements: Analysis of four independent inversion models, J. Geophys. Res., 116, D12305, doi:10.1029/2010jd014887, 2011.

Stephens, B. B., Gurney, K. R., Tans, P. P., Sweeney, C., Peters, W., Bruhwiler, L., Ciais, P., Ramonet, M., Bousquet, P., Nakazawa, T., Aoki, S., Machida, T., Inoue, G., Vinnichenko, N., Lloyd, J., Jordan, A., Heimann, M., Shibistova, O., Langenfelds, R. L., Steele, L. P., Francey, R. J., and Denning, A. S.: Weak northern and strong tropical land carbon uptake from vertical profiles of atmospheric $\mathrm{CO}_{2}$, Science, 316, 1732-1735, 2007. 
Stone, R.: A lofty idea for atmospheric research, Science, 254, 1732, doi:10.1126/science.254.5039.1732, 1991.

Thoning, K. W., Tans, P. P., and Komhyr, W. D.: Atmospheric carbon dioxide at Mauna Loa Observatory, 2, Analysis of the NOAA GMCC data, 1974-1985, J. Geophys. Res., 94, 85498566, 1989.

Vermeulen, A.: CHIOTTO Final Report, ECN-E-07-052, 2007.

Watai, T., Machida, T., Ishizaki, N., and Inoue, G.: A lightweight observation system for atmospheric carbon dioxide concentration using a small unmanned aerial vehicle, J. Atmos. Ocean. Tech., 23, 700-710, doi:10.1175/jtech1866.1, 2006.

Watai, T., Machida, T., Shimoyama, K., Krasnov, O., Yamamoto, M., and Inoue, G.: Development of an atmospheric carbon dioxide standard gas saving system and its application to a measurement at a site in the West Siberian forest, J. Atmos. Ocean. Tech., 27, 843-855, doi:10.1175/2009jtecha1265.1, 2009.
Wunch, D., Toon, G. C., Wennberg, P. O., Wofsy, S. C., Stephens, B. B., Fischer, M. L., Uchino, O., Abshire, J. B., Bernath, P., Biraud, S. C., Blavier, J. F. L., Boone, C., Bowman, K. P., Browell, E. V., Campos, T., Connor, B. J., Daube, B. C., Deutscher, N. M., Diao, M., Elkins, J. W., Gerbig, C., Gottlieb, E., Griffith, D. W. T., Hurst, D. F., Jiménez, R., Keppel-Aleks, G., Kort, E. A., Macatangay, R., Machida, T., Matsueda, H., Moore, F., Morino, I., Park, S., Robinson, J., Roehl, C. M., Sawa, Y., Sherlock, V., Sweeney, C., Tanaka, T., and Zondlo, M. A.: Calibration of the Total Carbon Column Observing Network using aircraft profile data, Atmos. Meas. Tech., 3, 1351-1362, doi:10.5194/amt3-1351-2010, 2010.

Yang, Z., Washenfelder, R. A., Keppel-Aleks, G., Krakauer, N. Y., Randerson, J. T., Tans, P. P., Sweeney, C., and Wennberg, P. O.: New constraints on Northern Hemisphere growing season net flux, Geophys. Res. Lett., 34, L12807, doi:10.1029/2007GL029742, 2007. 